Budi Rismayadi, Suroso

Vol 4 No 2

ISSN : 2541-6995

E ISSN : 2580-5517

\title{
ABSTRAK \\ PENGARUH MOTIVASI DAN DISIPLIN KERJA TERHADAP KINERJA KARYAWAN DI KAWASAN INDUSTRI KARAWANG
}

Oleh:

\author{
Budi Rismayadi ${ }^{1}$ \\ Suroso $^{2}$ \\ Fakultas Bisnis dan Ilmu Sosial \\ Universitas Buana Perjuangan Karawang \\ Email : budi.rismayadi@ubpkarawang.ac.id, \\ suroso@ubpkarawang.ac.id
}

\begin{abstract}
ABSTRAK
Penelitian ini bertujuan untuk mengetahui: (1) Hubungan motivasi dengan disiplin kerja di Kawasan Industri Karawang (2) Pengaruh parsial motivasi terhadap kinerja karyawan di Kawasan Industri Karawang (3) Pengaruh parsial disiplin kerja terhadap kinerja karyawan (4) Pengaruh simultan motivasi dan disiplin kerja terhadap kinerja karyawan di Kawasan Industri Karawang.

Penelitian ini dilakukan dengan menggunakan metode deskritif dan verifikatif, yaitu : mengumpulkan data, menyajikan data, menganalisis data, dan melakukan pengujian hipotesis, serta membuat kesimpulan dan saran. Sample dikumpulkan dengan metode Accidental sampling dengan jumlah sample sebanyak 128 responden. Teknik analisis data yang dugunakan Analisis jalur ( Path Analysis ). Dari hasil analisis data penelitian diperoleh beberapa kesimpulan sebagai berikut :

Hasil penelitian pada tarif signifikansi 5\% menujukan bahwa : (1) Terdapat hubungan antara motivasi dengan disiplin kerja. Di lihat dari nilai sig. 0,000 < 0,05 . Untuk hasil nilai person correlation sebesar 0.727 dan mempunyai nilai yang positif. (2) Diketahui nilai sig. untuk pengaruh parsial motivasi terhadap kinerja karyawan adalah sebesar $0,000<0,05$ dan nilai $\mathrm{t}$ hitung sebesar $3.568>\mathrm{t}$ tabel 1.979. Sehingga dapat disimpulkan bahwa H0 ditolak. (3) Diketahui nilai sig. untuk pengaruh parsial disiplin kerja terhadap kinerja karyawan adalah sebesar $0,000<0,05$ dan nilai t hitung sebesar $4.033>\mathrm{t}$ tabel 1.979. Sehingga dapat disimpulkan bahwa H0 ditolak.(4) Diketahui nilai signifikansi untuk pengaruh simultan motivasi dan disiplin kerja terhadap kinerja karyawan adalah sebesar $0,000<0,05$ dan nilai $\mathrm{F}$ hitung 53.001 $>\mathrm{F}$ tabel 3,07. Sehingga dapat disimpulkan bahwa $\mathrm{H}_{0}$ ditolak. Pengaruh motivasi dan disiplin kerja terhadap kinerja karyawan memiliki pengaruh secara simultan sebesar 0.457 atau $45.7 \%$, sedangkan sisanya $54.3 \%$ merupakan pengaruh variabel lain yang tidak diteliti
\end{abstract}

Kata kunci : Motivasi, Disiplin kerja, dan Kinerja karyawan. 


\title{
ABSTRACT \\ THE EFFECT OF MOTIVATION AND WORK DISCIPLINE ON EMPLOYEE PERFORMANCE IN THE KARAWANG INDUSTRY AREA
}

\author{
Budi Rismayadi $^{1}$ \\ Suroso $^{2}$ \\ Fakultas Bisnis dan Ilmu Sosial \\ Universitas Buana Perjuangan Karawang \\ Email : budi.rismayadi@ubpkarawang.ac.id, \\ suroso@ubpkarawang.ac.id
}

This study aims to determine: (1) The relationship between motivation and work discipline in the Karawang Industrial Estate (2) The partial influence of motivation on employee performance in the Karawang Industrial Estate (3) Partial effect of work discipline on employee performance (4) Simultaneous influence of motivation and work discipline on employee performance in the Karawang Industrial Estate.

This research was conducted using descriptive and verification methods, namely: collecting data, presenting data, analyzing data, and testing hypotheses, as well as making conclusions and suggestions. Samples were collected by accidental sampling method with a sample size of 128 respondents. The data analysis technique used is Path Analysis. From the results of the research data analysis, several conclusions were obtained as follows:

The results of the study at the 5\% significance rate indicate that: (1) There is a relationship between motivation and work discipline. In view of the sig value. $0.000<0.05$. For the results of the person correlation value of 0.727 and has a positive value. (2) The value of sig is known. For the partial influence of motivation on employee performance is $0.000<0.05$ and the $t$ value is $3.568>t$ table 1.979. So it can be concluded that $\mathrm{H} 0$ is rejected. (3) The value of sig is known. The partial effect of work discipline on employee performance is 0.000 $<0.05$ and the $\mathrm{t}$-value is 4.033> t table 1.979. So it can be concluded that $\mathrm{H} 0$ is rejected. (4) It is known that the significance value for the simultaneous effect of motivation and work discipline on employee performance is $0.000<0.05$ and the $\mathrm{F}$ value is 53.001> F table 3.07. So it can be concluded that $\mathrm{H} 0$ is rejected. The effect of motivation and work discipline on employee performance has a simultaneous effect of 0.457 or $45.7 \%$, while the remaining $54.3 \%$ is the influence of other variables not examined.

Keywords: Motivation, work discipline, and employee performance. 


\section{PENDAHULUAN}

Pada era globalisasi ini, perusahaan-perusahaan saling bersaing satu sama lain dalam kegiatan produksi untuk memenuhi kebutuhan para konsumennya. Para perusahaan harus mengelola dan menyeleksi sumber daya manusianya yang baik untuk memenuhi tujuan suatu perusahaan. Sumber daya manusia merupakan aspek yang penting untuk menunjang produktivitas sebuah perusahaan agar mampu bertahan di dalam ketatnya persaingan saat ini. Oleh karena itu, sebuah perusahaan harus mampu mengelola sumber daya manusianya dengan baik agar dapat meningkatkan produktivitas di perusahaan tersebut.

Kementrian perindustrian telah menyiapkan Provinsi Jawa Barat sebagai wilayah strategis untuk pembangun kawasan industri ada sebanyak 2.381,97 hektar di wilayah utara jawabarat yang telah dikembangkan menjadi 10 kawasan industri baru bertaraf nasional maupun internasional. Sekitar 35\% atau 851,97 hektare dari kawasan industri baru tersebut berada di Kabupaten Karawang. Pembangunan tersebut memiliki alasan tertentu, seperti menurut Dirjen Pengembangan Perwilayahan Industri Kementrian Perindustrian, pembangunan kawasan industri menjadi salah satu Proyek Strategis Nasional yang tertuang dalam Peraturan Presiden No. 58 Tahun 2017. Untuk itu, pemerintah pusat hingga tahun 2019 sudah menyiapkan sebanyak 1.040.522 tenaga kerja bersertifikat, khususnya untuk ditempatkan di sentra-sentra industri, baik itu di Pulau Jawa maupun kawasan industri lainnya.

Berdasarkan Pasal 1 UUPT No. 40/2007 pengertian Perseroan Terbatas (Perseroan) adalah badan hukum yang merupakan persekutuan modal, didirikan berdasarkan perjanjian, melakukan kegiatan usaha dengan modal dasar yang seluruhnya terbagi dalam saham, dan memenuhi persyaratan yang ditetapkan dalam undang-undang ini serta peraturan pelaksanaannya. Perusahaan menurut undangundang RI nomor 13 tahun 2003 adalah Setiap bentuk usaha yang berbadan hukum atau tidak, milik orang perseorangan, milik persekutuan, atau milik badan hukum, baik milik swasta maupun milik negara yang mempekerjakan pekerja buruh dengan membayar upah atau imbalan dalam bentuk lain, Usaha-usaha sosial dan usaha- 
usaha lain yang mempunyai pengurus dan mempekerjakan orang lain dengan membayar upah atau imbalan dalam bentuk lain.

Sementara itu Kabupaten Karawang di siapkan pemerintah sebagai kawasan industri modern melalui penerbitan Keppres Nomor 53 Tahun 1989 tentang Pengembangan Kawasan Industri. Ada beberapa kawasan industri yang berskala besar di Karawang, antara lain : Karawang International Industry City, Kawasan Mitra Karawang, Kawasan Surya Cipta, Kawasan Indotaisei, dan Kawasan Bukit Indah City di jalur Cikampek, dengan luas mencapai ribuan hektare. Karawang memiliki kawasan industri terluas di Indonesia, bahkan di Asia Tenggara, dengan total luas lahan industri mencapai 13,718 hektare atau 7,85 persen dari luas Kabupaten Karawang. Berdasarkan data dari situs Pemerintah Kabupaten Karawang, jumlah industri besar dan industri kecil mencakup industri otomotif, elektronik, tekstil, baja, manufaktur, farmasi, dan lain-lain. Lebih dari 50 persennya merupakan penanaman modal asing. Sejumlah investor juga menilai Karawang sebagai daerah yang cukup strategis dalam berinvestasi.

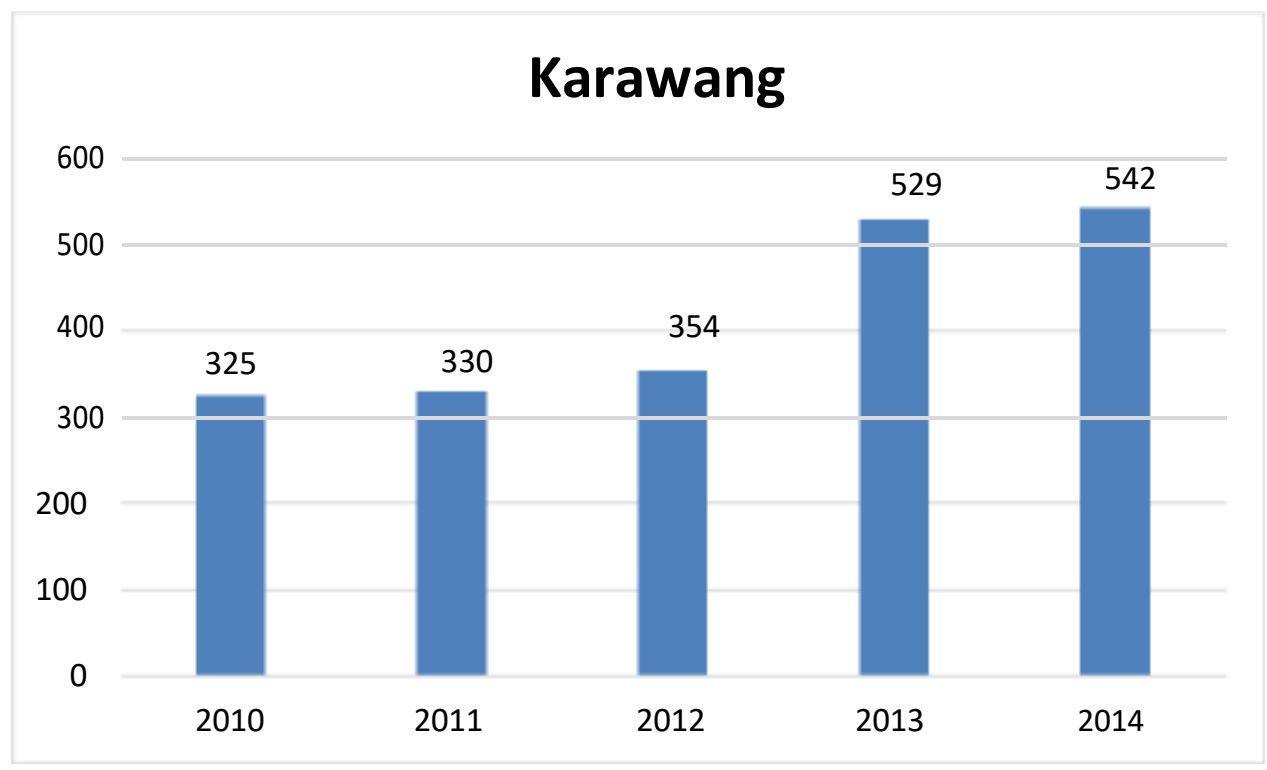

Sumber: Badan Pusat Statistik Provinsi Jawa barat

\section{Gambar 1.1}

Jumlah Industri Besar Sedang (Unit) di Kabupaten Karawang

Dapat di lihat dari Tabel 1.1 Jumlah perusahaan besar maupun sedang di Kabupaten Karawang tiap tahunnya selalu mengalami peningkatan dapat dilihat pada tahun 2010 perusahaan yang ada di Karawang sejumlah 325 perusahaan, pada 
tahun 2011 perusahaan di Karawang sejumlah 218 perusahaan, pada tahun 2012 perusahaan yang ada di Karawang sejumlah 354 perusahaan, pada tahun 2013 perusahaan di Karawang sejumlah 529 perusahaan, pada tahun 2014 perusahaan di Karawang sejumlah 542 perusahaan

Kawasan Industri Karawang merupakan sebuah perusahaan industri yang bergerak bidang kemasan plastik seperti botol dan tutup plastik, gelas plastik, jerigen dan preform PET, serta percetakan dekorasi dan pelabelan. PT Hasil Raya Industrieses Karawang yang berlokasi di Dsn Mangga Besar 2, Desa Walahar, Kec Klari Kawasan ABC, Karawang Timur, Kabupaten Karawang, Jawa Barat 41371. Berdasarkan fenomena di Kawasan Industri Karawang diketahui bahwa kedisiplinan kerja pada karyawan merupakan permasalahan yang masih dihadapi perusahaan saat ini, hal ini ditunjukkan dengan masih banyaknya karyawan yang kurang disiplin dan tanggung jawab terhadap kinerjanya. Karyawan yang malas akan mempengaruhi hasil produktivitas perusahaan dan akan menggangu kinerja karyawan yang lainnya. Agar karyawan tidak merasa malas, seorang karyawan atau pekerja harus termotivasi oleh hasrat yang positif dan memiliki semangat kerja yang baik dengan atas dorongan pemimpin perusahaan maupun atasan karyawan sendiri.

Keberhasilan suatu perusahaan dipengaruhi oleh kinerja individu atau pun kelompok. Suatu perusahaan akan berupaya untuk meningkatkan kinerja karyawannya dengan harapan dan tujuan perusahaan yang ingin tercapai. Hasibuan (2012:85) menyataan kinerja adalah perwujudan kerja yang dilakukan oleh seorang karywan yang biasanya yang dipakai untuk dasar penilain kerja terhadap karyawan atau organisassi. Perusahaan harus dapat memiliki produktivitas yang baik untuk memenuhi target perusahaan yang sudah ditetapkan. Kinerja karyawan yang baik dengan etos kerja yang tinggi akan membantu perusahaan untuk dapat memenuhi target perusahaan dan membantu perusahaan memperoleh keuntungan. Oleh karena itu, perusahaan harus selalu memperhatikan kebutuhaan para karyawannya agar supaya karyawan bekerja dengan maksimal dan mencapai target yang perusahaan ingin capai.

Penilaian kinerja di perusahaan itu sangat perlu, karena akan membawa dampak yang baik kepada perkerjaan yang di berikannya dan karyawan akan 
merasa punya rasa tanggung jawab kepada pekerjaannya. Perusahaan dituntut untuk selalu meningkatkan kinerja karyawan, agar perusahaan dapat terus bisa berkembang. Karena dengan adanya kinerja karyawan dalam diri setiap karyawan, maka mampu mengoptimalisasikan kemampuannya untuk melakukan pekerjaannya. Banyak faktor yang mempengaruhi kinerja karyawan diantaranya Kepemimpinan, Motivasi, Lingkungan kerja, Budaya Organisasi, Kepuasan kerja, Kompetensi.

Disiplin kerja itu sangat perlu diperusahaan. Oleh karena itu, setiap perusahaan selalu menuntut karyawannya disiplin dalam bekerja untuk mencapai hasil produktivitas yang diinginkan oleh perusahaan. Contoh displin dalam bekerja seperti memakai pakaian seragam kerja yang sudah ditetepkan oleh perusahaan, memakai ABPD sesuai dengan prosedur perusahaan, datang dan pulang kerja sesuai dengan waktu yang ditentukan dan masih banyak yang lainnya, dan sebaliknya jika karyawan yang kurang disiplin dalam bekerja. Karyawan yang kurang memiliki rasa disiplin kerja akan memepengaruhi orang-orang yang ada disekitarnya.

Dapat dilihat tabel dibawah Kawasan Industri Karawang masih memiliki tingkat absensi yang tinggi. Masih banyaknya karyawan yang mangkir, alfa, izin, dan surat dokter. Karyawan yang yang kurang disiplin dapat dipengaruhi oleh beberapa faktor contohnya seperti gaji dan kompensasi, peranan atasan, adanya peraturan tertulis dan adanya sanksi nyata.

Kedisiplinan di perusahaan tentu akan membuat lingkungan kerja yang sehat dan seimbang karena setiap karyawan menjalankan peran, fungsi dan tanggung jawabnya sesuai dengan aturan yang berlaku. Karyawan yang disiplin juga akan bekerja secara efektif dan efisien sehingga terhindar dari pemborosan waktu dan energi. Oleh karena itu, suatu perusahaan yang memiliki kedisiplinan tinggi tentu akan lebih mudah untuk mencapai tujuannya karena sistem atau aturan yang berlaku dapat dijalankan dengan baik oleh para karyawan.

Mangkunegara ( 2013:67 ) menyatakan motivasi merupakan unsur penting dalam ruang lingkup MSDM, keberadaan suatu motivasi sangat vital ketika berbicara dengan kinerja karyawan, karena kinerja yang baik di hasilkan dari motivasi yang baik. Pentingnya motivasi karena motivasi adalah hal yang 
menyebabkan, menyalurkan, dan mendukung perilaku manusia supaya mau bekerja giat dan antusias mencapai hasil yang optimal. Sedangkan menurut Sunyoto (2012:18) menyatakan motivasi merupakan cara mendorong semangat kerja seseorang, agar mau bekerja dengan memberikan secara optimal kemampuan dan keahlian guna mencapai tujuan organisasi. Pemberian motivasi pada karyawan itu sangat perlu di perusahaan. Supaya karyawan memiliki semangat dalam bekerja dan menghasilkan target sesuai keinginan perusahaan. Bila karyawan memiliki motivasi yang tinggi akan memeberikan kontribusi yang positif terhadap perusahaan dan memiliki rasa tanggung jawab terhadap kerjaannya.

\section{TINJAUAN PUSTAKA}

Manajemen adalah suatu proses untuk mewujudkan tujuan yang diinginkan. Manajemen tidak dilakukan oleh setiap perusahaan, tetapi juga dalam kehidupan sehari-hari seperti mengatur diri sendiri, keluarga, organisasi atau kelompok lainnya. Untuk lebih jelasnya berikut definisi manajemen menurut para ahli:

Menurut Malayu S.P Hasibuan (2013:2)

“ Manajemen adalah Ilmu dan seni mengatur proses pemanfaatan sumber daya manusia dan sumber-sumber lainnya secara efektif dan efisien untuk mencapai suatu tujuan tertentu."

Menurut Safroni (2012:44) Manajemen adalah Perencanaan, pengorganisasian, kepemimpinan, dan pengendalian upaya anggota organisasi dan proses penggunaan semua sumber daya organisasi untuk mencapai tujuan organisasi yang telah ditetapkan

Beberapa definisi menurut para ahli diatas dapat disimpulkan Manajemen adalah suatu ilmu dan seni perecanaan, pengorganisasian dan pengontrolan sumber daya manusia dalam guna mencapaian suatu tujuan yang tercapaiManajemen

\section{Sumber Daya Manusia}

Manajemen sumber daya manusia merupakan salah satu bidang dari manajemen umum yang meliputi perencanaan, pengorganisasian, pelaksanaan, dan pengendalian. Proses ini terdapat dalam fungsi atau bidang produksi, pemasaran, 
keuangan maupun kepegawaian. Berikut adalah beberapa definisi manajemen sumber daya manusia menurut para ahli :

Menurut Hasibuan ( 2013:10 )

“ Manajemen Sumber Daya Manusia adalah ilmu dan seni yang mengatur hubungan dan peranan tenaga kerja agar efektif dan efesien membantu terwujudnya tujuan perusahaan , karyawan, dan masyarakat. “

Sedangkan Menurut Mangkunegara ( 2013:2 )

“ Manajemen Sumber Daya Manusia adalah suatu perencanaan, pengorganisasian, pengkoordinasian, pelaksanaan, dan pengawasan terhadap pengadaan, pengembangan, pemberian balas jasa, pengintegrasian, pemeliharaan, dan pemisahaan tenaga kerja dalam rangka mencapai tujuan organisasi. “

Dari beberapa definisi menurut para ahli diatas dapat disimpulkan Manajemen Sumber Daya Manusia adalah suatu ilmu dan seni perencanaan, pengorganisasian, pengontrolan, yang mempunyai peranan dan fungsi penting dalam pengelolaan sumber daya manusia dalam perusahaan guna untuk mencapai keberhasilanya suatu perusahaan atau instansi.

\section{Motivasi}

Menurut Veithzal Rivai (2011:837) menyatakan motivasi adalah serangkaian sikap dan nilai-nilai yang mempengaruhi individu tuntuk mencapai hal yang spesifik sesuai dengan tujuan individu. Sikap dan nilai tersebut merupakan suatu yang invisible yang memberikan kekuatan untuk mendorong individu bertingkah laku dalam mencapai tujuan.

Sedangkan menurut Sunyoto (2012:11), menyatakan bahwa :

" motivasi merupakan sebuah dorongan yang tumbuh dalam diri seseorang, baik itu berasal dari dalam maupun berasal dari luar dirinya untuk melakukan suatu pekerjaan dengan semangat yang tinggi menggunakan semua kemampuan dan keterampilan yang dimilikinya."

Menurut Anwar Prabu Mangkunegara (2014:61),

"Motivasi adalah Kondisi atau energi yang menggerakkan diri karyawan yang terarah atau tertuju untuk mencapai tujuan organisasi perusahaan. “ 
Berdasarkan uraian pendapat dari para ahli diatas, dapat disimpulkan bahwa motivasi adalah suatu proses dorongan energi yang dihasilkan diri sendiri dan dapat dipengaruhi oleh lingkungan sekitar untuk melakukan kegiatan yang positif untuk mencapai suatu tujuan. Motivasi dapat dipengaruhi oleh adanya dukungan pemimpin terhadap bawahan, dan rekan kerja yang ada disekitar lingkungan perusahaan.

\section{Disiplin Kerja}

Disiplin kerja lebih banyak berasal dari kesadaran diri sendiri, yang diperlihatkan dalam bentuk mematuhi dan mentaati peraturan yang berlaku dalam melaksanakan pekerjaan di perusahaan maupun instansi.

Menurut Edy Sutrisno (2016:89) menyatakan :

“ Disiplin adalah perilaku seseorang yang sesuai dengan peraturan, prosedur kerja yang ada atau disiplin adalah sikap, tingkah laku, dan perbuatan yang sesuai dengan peraturan dari organisasi baik tertulis maupun tidak tertulis."

Menurut Malayu S.P Hasibuan (2012:193) menyatakan “ Disiplin kerja adalah kesadaran dan kesediaan seseorang menaati semua peraturan dan normanorma sosial yang berlaku.“

Berdasarkan uraian pendapat dari para ahli diatas, dapat disimpulkan bahwa Disiplin kerja adalah suatu perilaku seseorang yang sadar mentaati terhadap tanggung jawab dan peraturan dari organisasi atau perusahaan.

\section{Kinerja Karyawan}

Suatu perusahaan dibentuk untuk mencapai tujuan bersama, namun untuk mencapai tujuan secara efektif diperlukan kinerja yang baik. Kinerja merupakan perilaku nyata yang ditampilkan oseseorang sebagai prestasi kerja yang dihasilkan oleh karyawan sesuai peranan di perusahaannya. Dibawah ini pegertian kinerja yang dikemukakan oleh para ahli adalah sebagai berikut :

Menurut Veitzhal Rivai (2011:604) menyatakan :

“ Kinerja adalah suatu istilah secara umum yang digunakan untuk sebagian atau seluruh tindakan atau aktivitas dari suatu organisasi pada suatu periode dengan referensi pada sejumlah standar seperti biaya-biaya masa lalu atau 
Budi Rismayadi, Suroso

Vol 4 No 2

ISSN : 2541-6995

E ISSN : 2580-5517

yang diproyeksikan, dengan dasar efesiensi, pertanggung jawaban atau akuntabilitas manajemen dan semacamnya. " 
Sedangkan menurut Anwar Prabu Mangkunegara (2014:9) menyatakan :

“ kinerja karyawan adalah hasil kerja secara kualitas dan kuantitas yang dicapai oleh seseorang karyawan dalam melaksanakan tugasnya sesuai dengan tanggung jawab yang diberikan kepadanya. “

Menurut Moeheriono (2012:95) "Kinerja adalah gambaran mengenai tingkat pencapaian pelaksanaan suatu prgram kegiatan atau kebijakan dalam mewujudkan sasaran, tujuan, visi dan misi perusahaan yang dituangkan melalui perencanaan strategissuatu organisasi."

Beberapa definisi diatas kinerja adalah suatu hasil atau catatan tentang kegiatan pekerjaan yang dihasilkan dalam jumlah waktu yang ditentukan dan yang telah dicapai oleh suatu individu atau kelompok. Dalam kinerja karyawan dapat dipengaruhi dengan beberapa faktor antaranya kerjasama team dan kreatifitas karyawan.

\section{Hipotesis Penelitian}

H1 : Terdapat hubungan motivasi (X1) dan disiplin kerja (X2) di Kawasan Industri Karawang.

H2 : Terdapat pengaruh parsial motivasi (X1) terhadap kinerja karyawan (Y) di Kawasan Industri Karawang.

H3 : Terdapat pengaruh parsial disiplin kerja (X2) terhadap kinerja karyawan (Y) di Kawasan Industri Karawang.

H4 : Terdapat pengaruh simultan motivasi (X1) dan disiplin kerja (X2) berpengaruh terhadap kinerja karyawan (Y) di Kawasan Industri Karawang 


\section{METODE PENELITIAN}

\section{Metode yang Digunakan}

Metode penelitian pada dasarnya merupakan cara ilmiah untuk mendapatkan data dengan tujuan dan kegunaan tertentu. Cara ilmiah kegiatan penelitian itu didasarkan pada ciri-ciri keilmuan, yaitu rasional, empiris, sistematis Sugiyono (2011:2 ). Pada penelitian ini menggunakan metode penelitian deskritif dan verikatif.

Penelitian deskritif adalah penelitian yang dilakukan untuk mengetahui nilai variabel mandiri, baik satu variabel atau pun lebih ( independen ) tanpa membuat perbandingan, atau menghubungkan dengan variabel lainnya. Menurut Sugiyono (2011:8) bahwa metode penelitian kuantitatif dapat diartikan sebagai metode penelitian yang berlandaskan pada filsafat positivisme, digunakan untuk meneliti pada populasi atau sample tertentu, pengumpulan data menggunakan instrumen penelitian, analisis data bersifat kuantitatif/statistik dengan tujuan untuk menguji hipotesis yang telah ditetapkan.

Secara deskritif penelitian ini bertujuan untuk memperoleh gambaran mengenai variabel motivasi (X1) dan disiplin kerja (X2) sebagai variabel bebasnya dan variabel kinerja karyawan (Y) sebagai variabel terikat. Sedangkan secara verikatif bertujuan untuk menguji hipotesis dengan perhitungan statistik.

\section{HASIL PENELITIAN DAN PEMBAHASAN}

Responden yang akan digunakan adalah karyawan Kawasan Industri Karawang yang berlokasi di Dusun Mangga Besar 2, Desa Walahar, Kec Klari Kawasan ABC, Karawang Timur, Kabupaten Karawang, Jawa Barat 41371. Penelitian ini menggunakan metode penyebaran kuesioner pada karyawan Kawasan Industri Karawang pada Department produksi karyawan bagian injection dan karyawan bagian printing.

Untuk mendapatkan gambaran umum mengenai karyawan sebagai responden dalam penelitian ini maka berikut diuraikan : jenis kelamin, usia, dan masa kerja. 
Budi Rismayadi, Suroso

Vol 4 No 2

ISSN : 2541-6995

E ISSN : 2580-5517

1. Jenis Kelamin

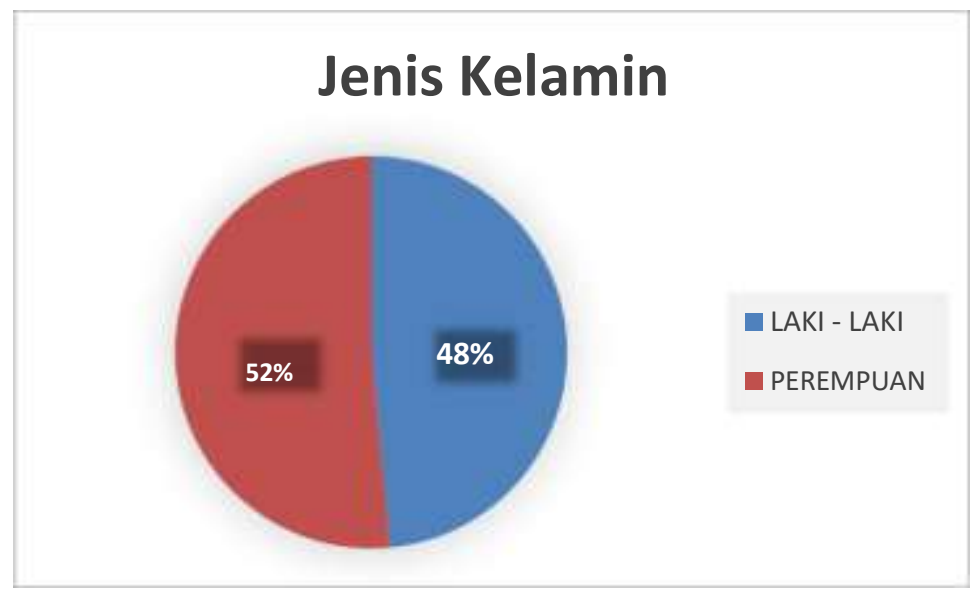

Gambar 4.2

Responden Menurut Jenis Kelamin

Sumber: Hasil pengelolaan data SPSS,2019

Dapat dilihat pada Gambar 4.2 di atas menujukan jumlah responden sebanyak 128 berdasarkan jenis kelamin adalah Laki-laki sebanyak $48 \%$ dan Perempuan sebanyak $52 \%$.

2. Usia

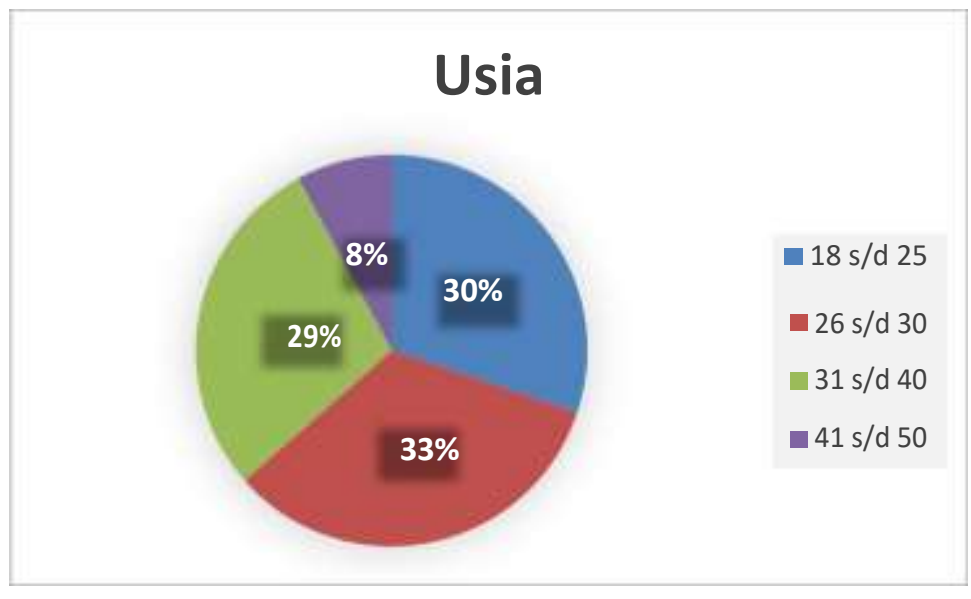

Gambar 4.3

Responden Menurut Usia

Sumber: Hasil pengelolaan data,2019

Dapat dilihat pada Gambar 4.3 di atas menujukan usia responden, presentase tertinggi pada usia 26 s/d 30 tahun sebanyak $33 \%$ dan paling rendah berusia $41 \mathrm{~s} / \mathrm{d} 50$ tahun sebanyak $8 \%$. 
Budi Rismayadi, Suroso

Vol 4 No 2

ISSN : 2541-6995

E ISSN : 2580-5517

3. Masa kerja

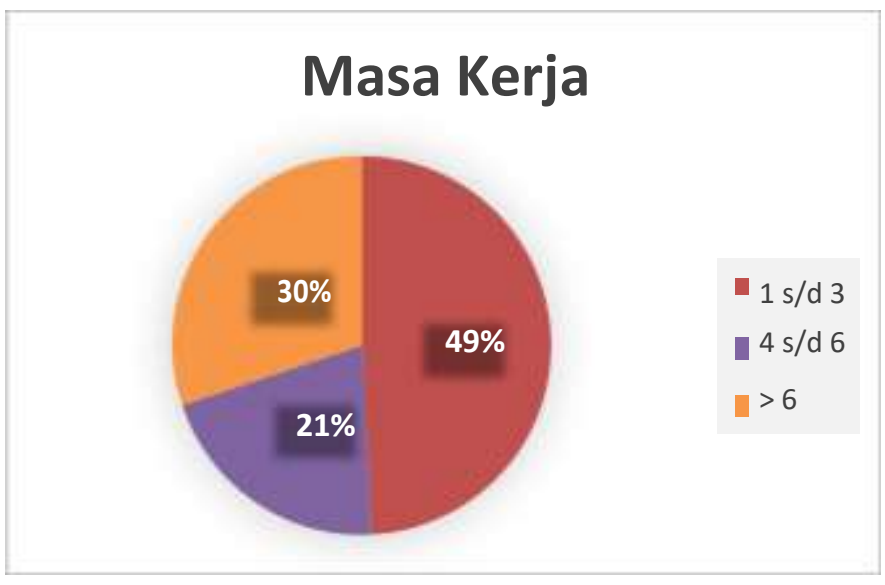

Gambar 4.4

\section{Responden Menurut Masa Kerja}

Sumber: Hasil pengelolaan data, 2019

Dapat dilihat pada Gambar 4.4 di atas menujukan masa kerja responden, presentase tertinggi pada masa kerja 1 s/d 3 tahun sebanyak $49 \%$ dan paling rendah pada masa kerja 4 s/d 6 tahun sebanyak $21 \%$.

Uji validitas yaitu item-item kuesioner yang harus dianalisis dengan langkah-langkah mengkorelasikan setiap skor item dan skor total pada SPSS yang merupakan jumlah setiap skor item.

Tabel 4.1

Motivasi

\begin{tabular}{|c|c|c|c|}
\hline Pertanyaan & r hitung & r tabel & Keterangan \\
\hline 1 & 0.566 & 1.978 & Valid \\
\hline 2 & 0.468 & 1.978 & Valid \\
\hline 3 & 0.313 & 1.978 & Valid \\
\hline 4 & 0.430 & 1.978 & Valid \\
\hline 5 & 0.517 & 1.978 & Valid \\
\hline 6 & 0.525 & 1.978 & Valid \\
\hline 7 & 0.541 & 1.978 & Valid \\
\hline 8 & 0.501 & 1.978 & Valid \\
\hline 9 & 0.539 & 1.978 & Valid \\
\hline
\end{tabular}


Budi Rismayadi, Suroso

Vol 4 No 2

ISSN : 2541-6995

E ISSN : 2580-5517

\begin{tabular}{|l|l|l|l|}
\hline 10 & 0.484 & 1.978 & Valid \\
\hline
\end{tabular}

Sumber: Hasil pengelolaan data SPSS,2019

Tabel 4.1 Lanjutan

Motivasi

\begin{tabular}{|c|c|c|c|}
\hline Pertanyaan & r hitung & r table & Keterangan \\
\hline 11 & 0.594 & 1.978 & Valid \\
\hline 12 & 0.516 & 1.978 & Valid \\
\hline 13 & 0.423 & 1.978 & Valid \\
\hline 14 & 0.619 & 1.978 & Valid \\
\hline 15 & 0.406 & 1.978 & Valid \\
\hline
\end{tabular}

Sumber: Hasil pengelolaan data SPSS,2019

Dapat dilihat di Tabel 4.1 hasil Uji Validitas Motivasi sebanyak 15 item kuesioner dinyatakan valid karena memiliki nilai $r$ hitung > $r$ tabel 1.978.

Tabel 4.2

Disiplin Kerja

\begin{tabular}{|c|c|c|c|}
\hline Pertanyaan & r hitung & $\mathrm{r}$ tabel & Keterangan \\
\hline 1 & 0.568 & 1.978 & Valid \\
\hline 2 & 0.440 & 1.978 & Valid \\
\hline 3 & 0.571 & 1.978 & Valid \\
\hline 4 & 0.555 & 1.978 & Valid \\
\hline 5 & 0.545 & 1.978 & Valid \\
\hline 6 & 0.533 & 1.978 & Valid \\
\hline 7 & 0.398 & 1.978 & Valid \\
\hline 8 & 0.500 & 1.978 & Valid \\
\hline 9 & 0.402 & 1.978 & Valid \\
\hline 10 & 0.500 & 1.978 & Valid \\
\hline 11 & 0.507 & 1.978 & Valid \\
\hline 12 & 0.539 & 1.978 & Valid \\
\hline 13 & 0.531 & 1.978 & Valid \\
\hline
\end{tabular}


Budi Rismayadi, Suroso

Vol 4 No 2

ISSN : 2541-6995

E ISSN : 2580-5517

\begin{tabular}{|c|c|c|c|}
\hline 14 & 0.476 & 1.978 & Valid \\
\hline 15 & 0.557 & 1.978 & Valid \\
\hline
\end{tabular}

Sumber: hasil pengelolaan data SPSS, 2019

Dapat dilihat di Tabel 4.2 hasil Uji Validitas Disiplin kerja sebanyak 15 item kuesioner dinyatakan valid karena memiliki nilai $r$ hitung > r tabel 1.978.

Tabel 4.3

Kinerja Karyawan

\begin{tabular}{|c|c|c|c|}
\hline Pertanyaan & r hitung & $\mathrm{r}$ tabel & Keterangan \\
\hline 1 & 0.525 & 1.978 & Valid \\
\hline 2 & 0.385 & 1.978 & Valid \\
\hline 3 & 0.442 & 1.978 & Valid \\
\hline 4 & 0.343 & 1.978 & Valid \\
\hline 5 & 0.337 & 1.978 & Valid \\
\hline 6 & 0.368 & 1.978 & Valid \\
\hline 7 & 0.473 & 1.978 & Valid \\
\hline 8 & 0.521 & 1.978 & Valid \\
\hline 9 & 0.473 & 1.978 & Valid \\
\hline 10 & 0.361 & 1.978 & Valid \\
\hline 11 & 0.518 & 1.978 & Valid \\
\hline 12 & 0.455 & 1.978 & Valid \\
\hline 13 & 0.303 & 1.978 & Valid \\
\hline 14 & 0.528 & 1.978 & Valid \\
\hline 15 & 0.544 & 1.978 & Valid \\
\hline
\end{tabular}

Sumber: hasil pengelolaan data SPSS, 2019

Dapat dilihat di Tabel 4.3 hasil Uji Validitas Kinerja karyawan sebanyak 15 item kuesioner dinyatakan valid karena memiliki nilai $r$ hitung $>r$ tabel 1.978. 


\section{Pembahasaan}

Penelitian ini bertujuan untuk mengetahui, mengkaji dan menganalisis pengaruh motivasi dan disiplin kerja terhadap kinerja karyawan. Demikian diperoleh dengan hasil sebagi berikut :

1. Berdasarkan hasil penelitian menunjukan bahwa motivasi pada karyawan Kawasan Industri Karawang dengan hasil kuesioner diperoleh nilai rata-rata skor sebesar 459.4 yang berada pada rentang skala 434.1 - 536.1 dengan kriteria baik. Artinya semua responden menilai semua indikator tersebut cukup terpenuhi akan tetapi harus lebih ditingkatkan lagi agar motivasi karyawan lebih maksimal.

2. Berdasarkan hasil penelitian menujukan bahwa disiplin kerja pada karyawan Kawasan Industri Karawang dengan hasil kuesioner diperoleh nilai rata-rata skor sebesar 466.5 yang berada pada rentang skala 434.1 - 536.1 dengan kriteria baik. Semua indikator disiplin kerja memiliki kiriteria baik. Artinya semua responden menilai semua indikator tersebut cukup terpenuhi akan tetapi harus lebih ditingkatkan lagi agar disiplin kerja karyawan lebih maksimal.

3. Berdasarkan hasil penelitian menujukan bahwa kinerja karyawan pada Kawasan Industri Karawang dengan hasil kuesioner diperoleh nilai rata-rata skor sebesar 477.5 yang berada pada rentang skala 434.1 - 536.1 dengan kriteria baik. Semua indikator kinerja karyawan memilik kriteria baik. Artinya semua responden menilai semua indikator tersebut cukup terpenuhi akan tetapi harus lebih ditingkatkan lagi agar kinerja karyawan lebih maksimal.

4. Terdapat hubungan antara motivasi dengan disiplin kerja. Dapat di lihat dari nilai sig. disiplin kerja $0,000<0,05$. Kemudian untuk hasil nilainya sebesar 0.715. jika melihat dari Pedoman untuk interpretasi atau koefisien korelasi terdapat diantara interval koefisien sebesar 0,60 - 0,799 dengan tingkat hubungan kuat. Dapat disimpulkan tingkat korelasi atau hubungan antara motivasi dengan disiplin kerja dapat dikatakan saling berhubungan dengan tingkat hubungan yang kuat. 
5. Pengaruh motivasi terhadap kinerja karyawan secara parsial di Kawasan Industri Karawang pada bagian injection dan bagian printing. Diketahui nilai sig. untuk pengaruh variabel motivasi terhadap kinerja karyawan adalah sebesar $0,007<0,05$ dan nilai t hitung sebesar $2.747>\mathrm{t}$ tabel 1.978. Sehingga dapat disimpulkan bahwa $\mathrm{H} 0$ ditolak yang berarti motivasi secara parsial berpengaruh terhadap kinerja karyawan.

6. Pengaruh disiplin kerja terhadap kinerja karyawan secara parsial di Kawasan Industri Karawang pada bagian injection dan bagian printing. Diketahui nilai sig. untuk pengaruh variabel disiplin kerja terhadap kinerja karyawan adalah sebesar 0,002 <0,05 dan nilai t hitung sebesar 3.123>t tabel 1.978. Sehingga dapat disimpulkan bahwa H0 ditolak yang berarti disiplin kerja secara parsial berpengaruh terhadap kinerja karyawan.

7. Pengaruh motivasi dan disiplin kerja terhadap kinerja karyawan secara simultan pada bagian injection dan printing di Kawasan Industri Karawang. Hal ini dapat dilihat berdasarkan output diketahui nilai signifikansi untuk pengaruh motivasi dan disiplin kerja secara simultan terhadap kinerja karyawan adalah sebesar $0,000<0,05$ dan nilai $\mathrm{F}$ hitung $30.224>\mathrm{F}$ tabel 3.07. Sehingga dapat disimpulkan bahwa $\mathrm{H}_{0}$ ditolak. Berarti variabel motivasi dan disiplin kerja terhadap kinerja karyawan memiliki pengaruh secara simultan.

\section{KESIMPULAN DAN SARAN}

\section{KESIMPULAN}

Berdasarkan hasil analisis dan pengujian dalam penelitian ini, maka dapat disimpulkan sesuai dengan hipotesis dalam penelitian sebagai berikut :

1. Motivasi pada karyawan Kawasan Industri Karawang dengan hasil kuesioner diperoleh nilai rata-rata skor sebesar 459.4 yang berada pada rentang skala 434.1 - 536.1 dengan kriteria baik.

2. Disiplin kerja pada karyawan Kawasan Industri Karawang dengan hasil kuesioner diperoleh nilai rata-rata skor sebesar 466.5 yang berada pada rentang skala 434.1 - 536.1 dengan kriteria baik. 
3. Kinerja karyawan pada Kawasan Industri Karawang dengan hasil kuesioner diperoleh nilai rat

4. a-rata skor sebesar 477.5 yang berada pada rentang skala 434.1 - 536.1 dengan kriteria baik.

5. Terdapat hubungan antara motivasi dengan disiplin kerja pada bagian injection dan printing di Kawasan Industri Karawang dengan nilai signifikan sebesar $0.000<0.05$ dengan nilai pearson nya 0,715 .

6. Terdapat pengaruh parsial motivasi terhadap kinerja karyawan pada bagian injection dan printing di Kawasan Industri Karawang dengan nilai sebesar $0.007<0.05$ dan nilai t hitung $2.747>\mathrm{t}$ tabel 1.978 .

7. Terdapat pengaruh parsial disiplin kerja terhadap kinerja karyawan pada bagian injection dan printing di Kawasan Industri Karawang dengan nilai sebesar $0.002<0.05$ dan nilai t hitung $3.123>\mathrm{t}$ tabel 1.978 .

8. Terdapat pengaruh simultan motivasi dan disiplin kerja terhadap kinerja karyawan pada bagian injection dan printing di Kawasan Industri Karawang dengan nilai signifikan sebesar $0.000<0.05$ dan nilai $\mathrm{F}$ hitung $30.224>\mathrm{F}$ tabel 3.07.

\section{SARAN}

Berdasarkan hasil analisis dan pengujian diperoleh variabel motivasi dan disiplin kerja terhadap kinerja karyawan pada bagian injection dan printing di Kawasan Industri Karawang. Dari hasil penelitian ini diharapkan dapat memeberikan perubahan atau saran kepada pihak tertentu, beberapa saran sebagai berikut :

1. Pimpinan Kawasan Industri Karawang harus selalu memberikan motivasi dan selalu memberikan kebutuhan karyawan. Agar tidak merasa malas, seorang karyawan atau pekerja harus termotivasi oleh hasrat yang positif dan memiliki semangat kerja yang baik.

2. Pimpinan Kawasan Industri Karawang selalu memberikan arahan atau perhatian yang lebih terhadap karyawan yang kurang disiplin kerja untuk mendorong kesadaran karyawan yang kurang tanggung jawab terhadap pekerjaan dan agar mampu meningkatkan disiplin kerja mereka. Selain 
pimpinan, pihak karyawan juga harus memiliki kesadaran diri akan kedisiplinan.

3. Penelitian ini juga dapat mempertimbangkan strategi-strategi yang yang lebih baik untuk meningkatkan disiplin kerja karyawannya dengan indiktorindikator yang telah dianalisa. Maka membentuk faktor-faktor yang dapat dijadikan saran dan refensi.

\section{DAFTAR PUSTAKA}

A.A Anwar Prabu Mangkunegara. 2009. Manajemen sumber daya manusia. Bandung : PT. Remaja Rosdakarya

Danang, Sunyoto. (2013). Metodologi Penelitian Akuntansi. Bandung: PT Refika Aditama Anggota Ikapi.

Edi Sutrisno. 2016. Manajemen Sumber Daya Manusia. Jakarta : Prenadamedia Group.

Handoko, T. Hani. 2011. Manajemen Personalia dan Sumberdaya Manusia. Yogyakarta: Penerbit BPFE

Hasibuan, Malayu S.P. 2010. Manajemen Sumber Daya Manusia. Jakarta: PT Bumi Aksara.

Hasibuan, Malayu S.P. 2016. Manajemen Sumber Daya Manusia. Edisi Revisi. Jakarta: Penerbit PT Bumi Aksara.

Kasiram, Moh. 2008. Metodologi Penelitian. Malang: UIN-Malang Pers.

Rivai, Veithzal. 2011, Manajemen Sumber Daya Manusia untuk Perusahaan: dari Teori ke Praktik, Jakarta : RajaGrafindo Persada

Sedarmayanti. 2009. Sumber Daya Manusia dan Produktivitas Kerja. Bandung: CV Mandar Maju.

Siagian, SP. (2008). Manajemen Sumber Daya Manusia. Cetakan Kesembilan. Jakarta: Bumi Aksara.

Sugiyono. 2014. Metode Penelitian Pendidikan Pendekatan Kuantitatif, Kualitatif Dan R\&D. Bandung: Alfabeta.

Sugiyono. 2012. Metode Penelitian Kuantitatif Kualitatif dan R\&D. Bandung: Alfabeta

Sutrisno. (2009), Manajemen Keuangan Teori, Konsep dan Aplikasi, Edisi Pertama, Cetakan. Ketujuh, Penerbit Ekonisia, Yogyakarta. 
Budi Rismayadi, Suroso

Vol 4 No 2

ISSN : 2541-6995

E ISSN : 2580-5517

S.P,Hasibuan, Malayu. 2013. Manajemen Sumber Daya Manusia. Jakarta: PT Bumi Aksara

Veithzal Rivai. (2011). Manajemen Sumber Daya Manusia Untuk Perusahaan Dari Teori Ke Praktek. PT. RAJAGRAFINDO PERSADA, Jakarta.

Nanang Yogi Anggoro Putro. 2017. Pengaruh Motivasi dan Disiplin kerja terhadap Kinerja Karyawan Outsourcing. Yogyakarta : Universitas Negri Yogyakarta

Muhammad Taufiek Rio Sanjaya. 2015. Pengaruh Disiplin kerja dan Motivasi terhadap knerja karyawan di Hotel ros in Yogyakarta. Yogyakarta : Universitas Negri Yogyakarta.

Annisa Pratiwi. 2014. Pengaruh Motivasi dan Disiplin kerja terhadap Kinerja pegawai ( Studi pada PT. Telekomunikasi Indonesia, Tbk Wilayah telkom pekalongan ). Semarang : Universitas Diponegoro

Rika Widaningtyas. 2016. Pengaruh Disiplin Kerja Dan Motivasi Kerja Terhadap Kinerja Karyawan (Studi pada PT. Macanan Jaya Cemerlang Klaten.). Yogyakarta : Universitas Negri Yogyakarta.

Sumber : Badan pusat statistik provinsi jawabarat jumlah industri besar sedang ( Unit ) di kabupaten karawang, 2003-2014. https://karawangkab.bps.go.id/statictable/2017/03/14/266/jumlahindustri-besar-sedang-unit-di-kabupaten-karawang-20032014.html Diakses 15-Desember-2018

Sumber : Badan Pusat Statistik Kabupaten Karawang Survei Industri Besar dan Sedang (Survei IBS) Kabupaten Karawang https://karawangkab.bps.go.id/news/2018/10/16/10/survei-industri-besar-dansedang--survei-ibs--kabupaten-karawang.html Diakses 15-Desember-2018

Sumber : Jawa Barat disiapkan menjadi kawasan industri Kamis, 05 Oktober 2017 / 18:37 WIB https://nasional.kontan.co.id/news/jawa-barat-disiapkan-menjadikawasan-industri Diakses 15-Desember-2018

Sumber : Karawang pusat ekonomi https://adv.kompas.id/2017/01/24/karawangpusat-ekonomi-baru/ Diakses 15-Desember-2018

Sumber : Undang-undang No.40 tahun 2007 https://www.ojk.go.id/sustainablefinance/id/peraturan/undang-undang/Pages/Undang-Undang-No.-40-tahun-2007tentang-Perseroan-Terbatas.aspx Diakses 15-Desember-2018 